\section{EARLY HISTORY OF THE ROYAL BOTANIC GARDEN, CALCUTTA}

\author{
BY Dr. D. CHATTERJEE \\ c/o Royal Botanic Gardens, Kew
}

\begin{abstract}
A GENERAL account of the Royal Botanic Garden, Calcutta, has been given by Biswas ${ }^{1}$, and some of the detailed incidents connected with the formation of the Garden are also available in the published papers by Anderson ${ }^{2}$ and King ${ }^{3}$. The Calcutta Garden is perhaps one of the oldest gardens in Asia, and it is not generally realized that it was established by the Honourable East India Company as early as 1787, essentially for the purpose of increasing the commercial riches of the Company, and not for the advancement of botanical knowledge in India and elsewhere. It was cleverly planned by an army officer, and the proposal was so attractive to the directors of the Company that they readily agreed to the establishment of such a garden. The detailed correspondence on the subject is preserved among the old records of the East India Company. This was made available to me through the courtesy of the Keeper of Records, India Office, London. Some of these letters have been published both by Anderson ${ }^{2}$ and $\mathrm{King}^{3}$, and it is not intended, therefore, to re-publish them here. The remainder of the letters afford other valuable and interesting information, and the purpose of this note is to reveal some of the lesser known facts regarding the origin and development of this garden.
\end{abstract}

Unfortunately the exact date on which the Garden was started is not clearly known. Carey ${ }^{4}$ says that it was started in March 1786-a statement which seems to be wrong from an examination of the correspondence, and which has been corrected by Anderson. Prior to the official sanction by the East India Company, part of the Garden existed around the country house of Lieut.-Colonel Robert Kyd. This plot of land formed the eastern part of the Botanic Garden after its formation and has been referred by Roxburgh $^{5}$ in connexion with a tree-Garcinia cornea Willd. The actual proposal for the establishment of a botanical garden near Calcutta was submitted to the then Governor-General (Sir John Macpherson) at Calcutta by Lieut.-Colonel Kyd on June 1, $1786^{6}$. It was clearly stated in this letter that the idea of establishing a botanic garden is "not for the purpose of collecting rare plants as things of mere curiosity, but for establishing a stock for disseminating such articles as may prove beneficial to the inhabitants as well as to the natives of Great Britain, and which ultimately may tend to the extension of the national commerce and riches". It was suggested that the proposed garden would grow teak for ship-building, various spices (such as cinnamon, cardamon, clove, black and white pepper and nutmeg) for sale in Europe, and other articles of commerce (such as cotton, tobacco, indigo, coffee, camphor, gum-yielding plants and tea). The proposal was duly supported by the Governor-General, who wrote by way of recommendation to the Directors of the East India Company, "the garden may be formed as a general plantation or nursery where the cultivation of the cinnamon and the different articles mentioned by Col. Kyd may be attempted". The cost of main. taining this garden was suggested by $\mathrm{Kyd}$ at the low figure of Rs. 150-200 per month?

Kyd derived this inspiration, which led to the suggestion of forming a botanic garden, possibly from two sources: (1) in the garden of the previous Governor-General (Warren Hastings), he found some flourishing cardamon trees growing, and also some natural seedlings which promised a "rising plantation" ; (2) Kyd himself was a keen gardener and at that time collected and grew, in the compound of his country house at Salimar, many foreign plants of economic and horticultural value. He used to secure these plants from the captains of the Company's ships returning from voyages to the Far East. Hence, his own experience had convinced him that some of the spices of the East Indies could be grown in India. If this could be achieved, it would have a further advantage, namely, the Dutch monopoly of the highly prized cinnamon and other spices would be broken.

The Court of Directors, too, as clever business heads of a commercial organisation, were alive to the benefits of this scheme. In their letter of approval, dated July 31, 1787, they duly stressed among other things the cultivation of cinnamon. This portion of their letter runs, "The experiment respecting the cinnamon tree in particular must be made in different parts and soils of those extensive provinces in order to ascertain with certainty whether this spice can be produced in Bengal equal to that which grows on the island of Ceylon ${ }^{8}$. We are aware that by extending your experiment too far, the expenses may increase to an amount of which you may not at present have any idea. But so sensible are we of the vast importance of the objects in view, that it is by no means our intention to restrict you in point of expense in the pursuit of it. In the cultivation of cinnamon tree in particular, we foresee a great source of wealth to the Company and of population and opulence to the provinces under your administration. Most earnestly therefore do we recommend it to you to proceed in your endeavours to propagate this spice in different places, and that you avail yourselves of the abilities and zeal of Lieutenant-Colonel Kyd herein."

The next step was the selection of a site and the acquisition of the land. This presented some diffculties. In his letter dated August 10, 1786, Kyd said that he, in company with a Mr. Hay, examined a plot of ground on the western bank of the river in the vicinity of Calcutta. One area which seemed suitable was not available, as on inquiry from $\mathrm{Mr}$. Jonathan Duncan, the revenue officer, Kyd learnt that the ground had been allotted to the followers of Tishore Lama of Tibet, and had been consecrated for religious purposes. Kyd had of necessity to forgo this plot and chose a second area where the fort of Muggah Tannah and the barracks of the Moorish garrison formerly stood. This fort fell to the British under the leadership of Clive at the time of recapture of Calcutta. It was then demolished by mining. The condition of part of this ground was stated to be "perfect wild, overgrown with brush wood and subject to the overflow of the tide". This ground was adjacent to a plot of land which Kyd already possessed, and where he had his country house with his garden. A portion of this area fell within the limits of the Burdwan district (the extended limit of that $\operatorname{tim} \theta$ ), and the Burdwan land was acquired from the Zamindar by exchanging an equivalent portion of East India Company's land elsewhere. Other lands of the Company, measuring 148 bighas 9 cottaks, were given to the residents of the ground, to induce them to leave the area, and the amount of compensation granted to them for their huts and personal effects was Rs. 3,166/4/0. 
Having obtained the ground, Kyd with 109 labourers started to dig a ditch round the plot of land and also erected a fence. The fence was necessary to exclude wild buffaloes, which frequently visited the area. The monthly cost of this work, excluding the bamboo fencing, amounted to Rs. 384/0/0, and the work must have taken several months, for we read in a letter of the Treasury Officer (Buxey), dated May 1, 1787, that Kyd has drawn "one thousand sicca rupees" for this purpose. This amount appears to be only an instalment.

Those readers who have visited the Royal Botanic Garden, Sibpur, Calcutta, will recall that the ditch made by $\mathrm{Kyd}$ still exists, and is fairly continuous around the Garden, even now. A part of the ditch, that is, the ditch which now separates the Bengal Engineering College from the Botanic Garden, existed earlier, as this ditch formed part of the boundary of the old fort of Muggah Tannah. The portion of land, east of this ditch, that is, part of the present area of the Bengal Engineering College, was Kyd's personal land. This was given (at least, the major part of it) to the Botanic Garden at the time of its formation (1786-87), and remained so until 1820. In that year the same portion was given to the Lord Bishop of Calcutta for the establishment of a College. It appears that this old ditch of Muggah Tannah thus formed a ditch of convenience at the time of handing away a part of the garden land for the purpose of Bishop College, and the same holds good as a good demarcating line even now. The original ground of Kyd's garden house was known under various names, such as Kyd's Garden, Royd's Garden, Barwell's Garden, and in 1819 as Metcalf's Garden.

The next stage was to lay out the Garden and to start the commercial plantation of cinnamon and other spices. In this, Kyd was unusually ambitious but he was never a botanist. These two facts led to the complete failure of the enterprise after a few years of experiment. His ambitious aspect is evident from the fact that he wanted to grow every desirable economic plant of every country in his Garden. By a voluminous correspondence with British agents in different parts of Asia, he secured an amazing variety of plants, such as Persian dates, Persian tobacco, Chinese tea, oranges, English apples, cherries, apricots, sandalwood from the Malabar coast, and other plants like black pepper, bread-fruit, and a number of gum-producing plants. All these were duly planted out; but, as was to be expected, most of them perished in the uncongenial climate and soil of Calcutta. The cultivation of teak was also abandoned for the same reason in later years ${ }^{11}$.

Kyd's term of honorary superintendentship of the Company's Botanic Garden was not a long one. His failure to grow so many commercial and economic plants should not be regretted by the present botanists of India, as his success (if it could have happened) might have altogether changed the destiny of the Garden. It appears to me that by his failure he paved the way to a botanic garden, which in the hands of his able successor played a very important part in the advancement of Indian botany. The name of Kyd should, however, be remembered with reverence as the founder of the Calcutta Garden which was destined to become a botanic garden and not a cinnamon plantation of the tea-garden type, on which so much stress was laid from the beginning, and at every stage.

Kyd died on March 26, 1793, and was buried in the South Park Street Cemetery in Calcutta. Two years later a memorial was erected in the Botanic Garden and a marble urn was placed on it. The site for this memorial was selected by Roxburgh", and the inseription on the urn says, "To the honour of Robert $\mathrm{Kyd}$, an officer of the army and founder of this garden; placed by A. K. 1795" ("Roberto Kyd, mil. trib. horti foundatori posuit A. K., MDCCXCV"). The initials A. K. refer to his relation, Alexander Kyd, who was then a major in the Bengal Engineers, and who later constructed the Kidderpore docks.

Kyd was succeeded by Dr. William Roxburgh, who on November 29, 1793, was appointed the first salaried superintendent of the East India Company's Botanic Garden. It was Roxburgh who got a sanction of Rs. 15,000 to build quarters for the Superintendent. This house was completed after 1795, and Roxburgh's request for a further sum of Rs. 5,000 (presumably over-spent in building the house) was refused by the Company. This house is a three-storied building on the river-bank and is still occupied by the Superintendent of the Garden.

During and since Roxburgh's tenure of office, the Botanic Garden near Calcutta has attracted the attention of the scientific world, and the scientific study of Indian plants dates from his time. (A few years prior to Roxburgh, Dr. Koenig was in India. Roxburgh regarded him as an intimate friend and also his preceptor. Koenig was essentially a plant collector who sent his plants to Linnæus (father and son) and Retzius.) Roxburgh has been, therefore, rightly called the 'father of Indian botany'.

It will be easily understood that, under the direction of a man of science such as Roxburgh, devoted to the scientific study of Indian plants, the original aims of the Garden as emphasized by the directors of the Company were not followed. Much about the same time the East India Company was being gradually eclipsed by the British Government. This was being done through the provisions of Pitt's India Act, and as such the control over Roxburgh became less and less effective. This allowed him to carry on as he liked.

For official purposes, the date of actual sanction to the proposal of establishing a botanic garden by the court of directors of the East India Company (that is, July 31, 1787) should be regarded as the beginning of the Garden. Prior to this date only a part of the Garden existed around Kyd's country house, which was included later within the botanical garden com. pound in 1787. On the basis of this date, the Royal Botanic Garden, Calcutta (as it is now known), completed its 150th year on July 30, 1937, and this was celebrated in a fitting manner on January 6 , 1938. The latter date was apparently fixed for the sake of convenience only, as many British and foreign men of science, including the Director of the Royal Botanic Gardens, Kew, happened to be present in India at that time.

The East India Company during the years 1786-87 governed the country, collected the revenue, and administered law and order. Yet constitutionally its position was like that of landlord under the Nawab of Bengal. The Company at that time was still a private trading company, and could not be regarded as a part of the British Government. Robert ${ }^{10}$ says, "the constitutional relation between the Nawab of Bengal and the East India Company at that time was indeed complicated. The Company secured the administration of military power and criminal justice (Nizamat) from the Nawab, and the power to collect revenue and administer civil justice (Diwani) from 
the Moghul Emperor." The above statement elearly shows that the East India Company was actually ruling the country under the shadow of the Nawab of Bengal. The Nawab was relieved of this heavy responsibility, as he got annually more than 40 lacs of rupees from the Company as lease-money. This position was cleverly stated by Clive thus, "the Nawab had only the name and shadow of authority, yet this name . . . this shadow, it is indispensably necessary that we should venerate".

This relationship should be clearly understood, as this represented the last days of the Moghul period, a dark period of the East India Company, and the formative phase of the British rule. Unless this is understood, one is liable to assume that the East India Company really represented the British Government at that time.

${ }^{1}$ Biswas, K., "150th Anniversary Volume of the Royal Botanic Garden, Calcutta", 2-12 (1942).

${ }^{2}$ Anderson, T., J. Agric. Hort. Soc. India, N.S., 1, 169 (1869).

- King, G., Ann. Roy. Bot. Gard., Calcutta, 4, Pt. 1, i-xi (1893).

'Roxburgh, W., "Hortus Bengalensis", 2 (1814).

s Roxburgh, W., "Flora Indica", 2, 629 (1832).

- This date is given as January 1, 1786, by Biswas (l.c. 2). This is probably a printer's error

'An idea of the present-day cost can be formed from the amount spent in 1944-45, which was Rs. 1,20,928.

At that time Ceylon was under the Dutch Government.

- Biswas' statement on this point is contradictory (l.c. 2). King says (l.c. 3 ) that this site was selected by Roxburgh and not by Kyd himself, as stated by Biswas.

10 Robert, P. E., "Historical Geography of the British Dependencies", 7, India, Pt. 1 (1916).

$"$ King, l.e., iii.

\section{TRACE ELEMENTS IN PLANT PHYSIOLOGY}

$U^{2}$

NDER the auspices of the International Union of Biological Sciences, a symposium on "Trace Elements in Plant Physiology" was held at Rothamsted Experimental Station, Harpenden, under the chairmanship of Prof. B. Nemec, of Prague, during November 5 and 6,1947 . Representatives from many countries attended.

The symposium was conducted in four sessions, at which fourteen short papers were read to introduce the subjects for discussion. The work in progress on trace elements under Drs. Winifred Brenchley and Katherine Warington at the Rothamsted Station was inspected at the end of the meetings.

On the evening of November 6 the members of the conference were entertained at an after-dinner function at the Rothamsted Laboratories by the Director, Dr. W. G. Ogg, and the staff of the Station, when the delegates met senior members of Rothamsted concerned with trace-element investigations.

The subjects presented in the papers for discussion covered a wide field and included items of current scientific interest and practical importance, and demonstrated the immense value of plant physiological studies in investigating problems of crop production and animal husbandry.

Prof. Nemec, in his opening address, outlined the development of methods of research on trace elements, referring in particular to the early water culture experiments of Sachs and the influence of Prof. Stoeckard, of Tharandt Forestry School, Saxony, on this pioneer work. He exhibited a sample of gold obtained from the ash of plants of Equisetum palustre grown on volcanic soils in Bohemia, and referred to the concentration of droplets of metallic mercury in the seed capsules of Holosteum umbellatum on some soils.
Prof. T. Wallace and Dr. E. J. Hewitt (Great Britain) outlined methods in use in trace-element research at Long Ashton. It was shown how visual methods can be applied to problems of deficiencies, excesses and relationships of trace elements in plant nutrition studies, and how the method can be applied to analyse the injurious effects of soil acidity. Dr. Hewitt described his technique for large-scale sand cultures by means of which he has been able to study problems relating to deficiencies of iron, manganese, boron and molybdenum. The various points of these two papers were illustrated by a comprehensive exhibit of photographs.

Prof. J. Lavollay (France) outlined his method for the determination of the coefficient of action of mineral nutrients and illustrated the application of the method to problems concerning magnesium nutrition, showing how yield is related not only to the supply of magnesium in the nutrient, but also to the total concentration of salts in the medium. $\mathrm{He}$ demonstrated the beneficial effect of phosphorus on the action of magnesium and the antagonism which exists between magnesium and potassium; also the similarity of action of potassium and rubidium.

Dr. D. I. Arnon's (U.S.A.) contribution concerned the criteria of essentiality for micro-nutrients, and he illustrated his points by reference to his investiga. tions in California on the essential role of molybdenum in plant nutrition. $\mathrm{He}$ suggested as the three criteria of essentiality of any element: (1) the life-cycle of the plant cannot be completed if the element is omitted; (2) the action of the element must be specific; (3) the effect on the plant must be direct. The paper and the discussion revealed the great practical difficulties of establishing 'essentiality' for elements required only in traces; but nevertheless it was thought that refinements of methods might disclose the essential nature of further elements.

Points of special interest in trace element nutrition were discussed in papers by Dr. E. G. Mulder (Holland), Dr. J. Erkama (Finland), and Prof. $H$. Burström (Sweden). Dr. Mulder described experiments concerning the functions of copper and molybdenum in the metabolism of higher plants and micro-organisms, and also referred to the application of his results to field crops in the Netherlands. Copper is regarded as a catalyst of oxidation processes, and molybdenum has been shown to be necessary for the reduction of nitrate nitrogen in higher plants and for the fixation of nitrogen by Azotobacter.

Dr. Erkama in his studies has regarded the three elements iron, manganese and copper as comprising one unit, and has endeavoured to determine their relationships. Manganese seems to be antagonistic to both copper and iron, and reactions with man. ganese seem to take place mainly in the vacuole sap. Copper, it is suggested, is able to remove iron from the vacuole sap and to oxidize it in protoplasm.

Prof. Burström reported results on the action of manganese in roots. Manganese appears to catalyse nitrate reduction in roots, and in this respect it may have a similar function to molybdenum in some plants. His results show that in roots, nitrogen increases the length of cells, phosphorus is concerned with cell multiplication, while manganese appears not to affect the ultimate length of the root. Manganese may shorten the meristem region, and while increasing the rate of root elongation it also shortens the 'grand period' of growth. Manganese thus seems to have effects apart from those concerned with nitrogen. Arising from this paper, the differential 